\title{
Safety Training as a Predictor of Seafarers Performance
}

\author{
Rini Nurahaju and Dessy Nur Utami \\ Departement of Psychology, Universitas Hang Tuah, Surabaya \\ e-mail: rini.nurahaju@hangtuah.ac.id
}

\begin{abstract}
A good performance of seafarers is expected by any shipping company because it will bring benefits to the company itself. In order to get this performance, seafarers as one of the important assets must be managed properly by the company. One of them is the participation of seafarers to attend training for mutual safety. The purpose of this study was to analyse the effect of training on seafarers' performance. The sample in this study amounted to 100 seafarers who happened to be attending education in educational institution, which were selected using incidental sampling techniques. Research uses a training scale and a performance scale to measure seafarers' perceptions of training that has been conducted and performance as a result. Data were analysed using a simple regression test. Regression test results show that training has a positive and significant role on the performance of seafarers.
\end{abstract}

Keywords-The effect of Training Seafarers, Safety Training, Simple Regression Test.

\section{INTRODUCTION}

$\mathrm{Q}$ UALITY of Human Resources (HR) is determined by the extent to which the system in the HR field is able to support and satisfy the desires of employees and companies. The better the capabilities of HR, the better the results achieved. Without the support of qualified HR will have an impact on performance and hinder the achievement of the company's goals. This is also experienced by shipping companies. The importance of this research is due to seafarers as the main actors in every operational activity of a shipping company.

Performance is the ability to work or something that is achieved or achievements that are shown [1]. Performance is the total value expected by the organization of individual behaviours over a certain period [2]. It is widely agreed that performance is multidimensional [3]. Employee performance includes task performance and non-task performance or also called contextual performance [2]. Task performance includes behaviours that contribute to the core activities and maintenance within an organization [3]. Task performance can be defined as the ability in which a person performs his work duties. Contextual performance, in contrast, refers to behaviours that contributes to the culture and climate of the organization.

This contextual performance includes interpersonal facilitation behaviours and job dedication behaviours. Interpersonal facilitation behaviours is interpersonal oriented behaviours that contributes to the performance of organizational goals. Interpersonal facilitation behaviours includes a variety of interpersonal actions that help maintain social and interpersonal contexts needed to support the effectiveness of task performance in organizations. Job dedication behaviours is centered on self-discipline

\begin{tabular}{ccc}
\multicolumn{4}{c}{ Table 1. } \\
Sex \\
\hline \hline Sex & Frequency & Percent \\
\hline Male & 85 & 85 \\
Female & 3 & 3 \\
Missing & 12 & 12 \\
aTotal & 100 & 100 \\
\hline \hline \multicolumn{4}{c}{ Table 2.} \\
\multicolumn{4}{c}{ Frequency } \\
\hline \hline Year of Services & 47 & Percent \\
\hline $1-10$ & 42 & 47 \\
$11-20$ & 6 & 42 \\
$21-30$ & 2 & 6 \\
$31-40$ & 3 & 2 \\
Missing & 100 & 3 \\
Total & Tef Services \\
& Table 3. & 100 \\
\hline & Marital Status & \\
\hline \hline Marital Status & Frequency & Percent \\
\hline Married & 78 & 78,0 \\
Single & 9 & 9,0 \\
Missing & 13 & 13,0 \\
Total & 100 & 100,0 \\
\hline \hline
\end{tabular}

behaviours including following the rules, working hard, and taking the initiative to solve problems in the workplace [4].

The performance of each seafarer varies, therefore exploration is needed regarding the factors that play a role in seafarers' performance. Increased knowledge, skills, changes in attitude, behaviours, correction of seafarers' performance deficiencies are needed to increase their productivity and performance. Training is an activity to improve one's workability. Training helps employees understand a practical knowledge and its application, in order to improve the skills and attitudes needed by the organization in its efforts to achieve goals. Training is a process of teaching new or old employees the basic skills they need to carry out their work [5]. Employees, whether new or already employed need to attend training because of the demands of work that can change due to changes in the work environment, strategy, and forth.

Training is one of the efforts in improving the quality of human resources in the world of work. Training and development are very important for the workforce to work more masterfully and better at the work they do. The training will provide opportunities for seafarers to develop their skills and abilities to work thus what is known and mastered now and in the future can help them understand what is actually done and why it must be done, providing opportunities to add knowledge, expertise.

The 2014 World Maritime Council Session set the theme of 2015 International Maritime Day with "Maritime Education and Training". This shows how important education and training (training) is for maritime workers. 
Table 4.

Item-Total Statistics Before Elimination

\begin{tabular}{|c|c|c|c|c|c|}
\hline & $\begin{array}{c}\text { Scale Mean if Item } \\
\text { Deleted }\end{array}$ & $\begin{array}{l}\text { Scale Variance if } \\
\text { Item Deleted }\end{array}$ & $\begin{array}{c}\text { Corrected Item-Total } \\
\text { Correlation }\end{array}$ & $\begin{array}{c}\text { Squared Multiple } \\
\text { Correlation }\end{array}$ & $\begin{array}{l}\text { Cronbach's Alpha if } \\
\text { Item Deleted }\end{array}$ \\
\hline Item 1 & 68,5500 & 31,038 & ,696 & ,603 & ,798 \\
\hline Item 2 & 68,6600 & 31,257 &, 500 &, 547 & ,807 \\
\hline Item 3 & 68,7400 & 32,396 & ,498 & ,490 & ,808 \\
\hline Item 4 & 68,6300 & 31,993 & 638 &, 568 & 803 \\
\hline Item 5 & 68,9200 & 32,337 &, 445 & ,390 &, 810 \\
\hline Item 6 & 68,5800 & 32,428 &, 574 & ,506 & ,806 \\
\hline Item 7 & 68,7200 & 31,497 &, 553 & ,498 & ,804 \\
\hline Item 8 & 68,6800 & 31,876 &, 557 &, 550 &, 805 \\
\hline Item 9 & 68,8000 & 31,293 &, 504 &, 424 & ,806 \\
\hline Item 10 & 68,8100 & 31,751 & ,516 & ,462 & ,806 \\
\hline Item 11 & 68,9400 & 30,946 &, 500 &, 510 &, 806 \\
\hline Item 12 & 68,4400 & 32,774 &, 453 & ,539 &, 811 \\
\hline Item 13 & 70,2700 & 38,785 &,- 281 &, 343 & ,889 \\
\hline Item 14 & 68,5200 & 32,717 & ,403 & ,494 &, 813 \\
\hline Item 15 & 68,5900 & 32,244 &, 563 & 679 &, 806 \\
\hline Item 16 & 68,6400 & 32,920 & ,388 &, 375 & ,813 \\
\hline Item 17 & 68,6300 & 31,811 & ,644 &, 594 &, 802 \\
\hline Item 18 & 68,8200 & 32,513 &, 441 &, 356 &, 811 \\
\hline
\end{tabular}

Table 5.

Reliability Statistics Before Elimination

\begin{tabular}{|c|c|c|c|c|c|}
\hline Cronbach's Alpha & \multicolumn{4}{|c|}{ Cronbach's Alpha Based on Standardized Items } & $\mathrm{N}$ of Items \\
\hline ,821 & \multicolumn{3}{|c|}{, 873} & \multicolumn{2}{|r|}{18} \\
\hline \multicolumn{6}{|c|}{$\begin{array}{c}\text { Table } 6 . \\
\text { Item-Total Statistics After Elimination }\end{array}$} \\
\hline & $\begin{array}{l}\text { Scale Mean if } \\
\text { Item Deleted }\end{array}$ & $\begin{array}{l}\text { Scale Variance if } \\
\text { Item Deleted }\end{array}$ & $\begin{array}{l}\text { Corrected Item-Total } \\
\text { Correlation }\end{array}$ & $\begin{array}{l}\text { Squared Multiple } \\
\text { Correlation }\end{array}$ & $\begin{array}{l}\text { Cronbach's Alpha if } \\
\text { Item Deleted }\end{array}$ \\
\hline Performance & 66,0000 & 33,596 & ,717 & ,599 & ,876 \\
\hline Item 1 & 66,1100 & 33,978 & ,498 &, 539 & 884 \\
\hline Item 2 & 66,1900 & 34,964 &, 527 & 490 & 883 \\
\hline Item 3 & 66,0800 & 34,701 & 642 &, 565 & 880 \\
\hline Item 4 & 66,3700 & 35,044 & 450 &, 389 & ,886 \\
\hline Item 5 & 66,0300 & 34,837 & 634 & ,492 & ,880 \\
\hline Item 6 & 66,1700 & 34,304 &, 539 & ,498 & 882 \\
\hline Item 7 & 66,1300 & 34,397 &, 588 &, 549 & 881 \\
\hline Item 8 & 66,2500 & 33,846 &, 524 &, 410 & ,883 \\
\hline Item 9 & 66,2600 & 34,578 &, 501 &, 458 & 884 \\
\hline Item 10 & 66,3900 & 34,058 & 451 & 478 & 887 \\
\hline Item 11 & 65,8900 & 35,230 &, 502 &, 530 & ,884 \\
\hline Item 12 & 65,9700 & 34,999 & ,472 & ,490 & ,885 \\
\hline Item 14 & 66,0400 & 34,503 & ,644 & ,658 & 879 \\
\hline Item 15 & 66,0900 & 35,477 & ,419 & 374 & ,886 \\
\hline Item 16 & 66,0800 & 34,256 & 691 &, 593 & ,878 \\
\hline Item 17 & 66,2700 & 35,351 &, 428 &, 350 & 886 \\
\hline
\end{tabular}

The foundation used by the members of the IMO (International Maritime Organization) Council to set the theme is thus all parties realize how important the Maritime Human Resources (HR) is in ensuring more secure shipping safety on an ongoing basis.

Chairperson of the Indonesian National Ship-owner Association (INSA) or the 2011-2015 Indonesian National Commercial Shipping Business Entrepreneur, Carmelita Hartoto, said that without being manned by well-educated and trained seafarers, it was believed that shipping safety, security, and maritime environmental pollution could be threatened at any time. This can result in sluggish business in the maritime sector. According to him, maritime training is a stepping stone (bedrock) in an effort to achieve a safe, safe, and protected marine environment from continuous pollution. This is also in accordance with the previous author's research on cultural values in shipping companies that the value of safety is important in the world of sea transportation [6].

The 1978 STCW Convention and Code which was amended in Manila in 2010 was adopted and accepted by all countries which ratified and acceded to the convention and has been implemented. IMO members (including Indonesia) want to ensure that by applying the curriculum and syllabus of maritime training and competence that meets the provisions of the 1978 STCW Code which have been amended, able to produce seafarers with knowledge and skills that can improve, both shipping safety, security, and protection of the maritime environment from pollution. This will increase the confidence of stakeholders in the maritime industry in their business. In line with this, the IMO Secretariat, both in discussions at the sessions and in the form of a circular, always appealed to all countries to pay attention to whether the maritime training in their country had fulfilled the stipulated provisions. In addition, whether the implementation meets the competencies as mandated in the STCW Code-A.

Based on the previous explanation, the researcher aims to analyses the effect of safety training on the performance of seafarers. This research is important to be done as a form of contribution in improving the performance of seafarers, especially considering the safety risks at sea. This research is 
$2^{\text {nd }}$ Maritime Safety International Conference (MASTIC) 2020

July $18^{\text {th }}, 2020$, Surabaya

Table 7.

Reliability Statistics After Elimination

\begin{tabular}{ccc}
\multicolumn{3}{c}{ Reliability Statistics After Elimination } \\
\hline \hline Cronbach's Alpha & $\begin{array}{l}\text { Cronbach's Alpha Based } \\
\text { on Standardized Items }\end{array}$ & N of Items \\
\hline, 889 &, 895 & 17 \\
\hline \hline
\end{tabular}

Table 8.

Category Level of Training $(\mathrm{N}=100)$

\begin{tabular}{ccc}
\multicolumn{3}{c}{ Category Level of Training $(\mathrm{N}=100)$} \\
\hline \hline Categories & Total Score & Frequency \\
\hline High & $\mathrm{X}>70,73$ & $27(27 \%)$ \\
Medium & $64<\mathrm{X}<70,73$ & $52(52 \%)$ \\
Low & $\mathrm{X}<64$ & $21(21 \%)$ \\
\hline \hline
\end{tabular}

Table 9.

Category Level of Performance $(\mathrm{N}=100)$

\begin{tabular}{ccc}
\multicolumn{3}{c}{ Category Level of Performance $(\mathrm{N}=100)$} \\
\hline \hline Categories & Total Score & Frequency \\
\hline High & $\mathrm{X}>73$ & $26(26 \%)$ \\
Medium & $67<\mathrm{X}<73$ & $50(50 \%)$ \\
Low & $\mathrm{X}<67$ & $24(24 \%)$ \\
\hline \hline
\end{tabular}

Table 10.

Simple Regression Test: Effect of Training on Seafarers' Performance

\begin{tabular}{ccccc}
\hline \hline Variable & $\begin{array}{c}R- \\
\text { square }\end{array}$ & $F$ & $\operatorname{Sig}(p)$ & $\begin{array}{c}\text { Regression } \\
\text { Equation }\end{array}$ \\
\hline Performance & 0,445 & 78,478 & 0,00 & $\mathrm{Y}=23,100+$ \\
& & & & $0,703 \mathrm{X}$ \\
\hline \hline
\end{tabular}

expected to be able to add insight and enrich the results of existing research. In addition, the results of the study are also expected to provide information to seafarers and shipping companies about the urgency of training for seafarers' performance. Researchers predict that when seafarers have high skills in training, seafarers' performance will also increase. Therefore the statement of the research hypothesis is that there is an effect of safety training on seafarers' performance.

\section{METHOD}

This research is a type of explanative associative research. Associative research is one research design that aims to find the relationship between one variable with another variable [7]. In addition, in this case, it want to be measured is the extent to which training can explain the appearance of seafarers' performance.

The selected research participants are seafarers with active seafarers characteristics from various shipping companies. Taking participants is in a particular educational institution because it is based on reasons of accessibility and efficiency. The sampling technique used was incidental sampling, because the data collection process was in accordance with the accessibility and availability of participants at the time the data was collected.

From the results of data collection as shown on Table 1, 2, an 3, participants were aged 23-55 years. The majority of participants were male $(96.6 \%)$, but as many as 12 people did not answer. Related to marital status, dominant participants were married $(89.7 \%)$, but as many as 13 people did not answer. Their working period starts from 3 years to 24 years, but there are participants who did not fill the work period of 3 people. In more detail, those who have 1-10 years of service are $48.5 \%, 11-20$ years of service are $43.3 \%$, while those of 21-30 years are $6.2 \%$ and those who have $31-$ 40 years of service as much as $2.1 \%$.

The research instrument consisted of two scales, namely the training scale and the performance scale. The training

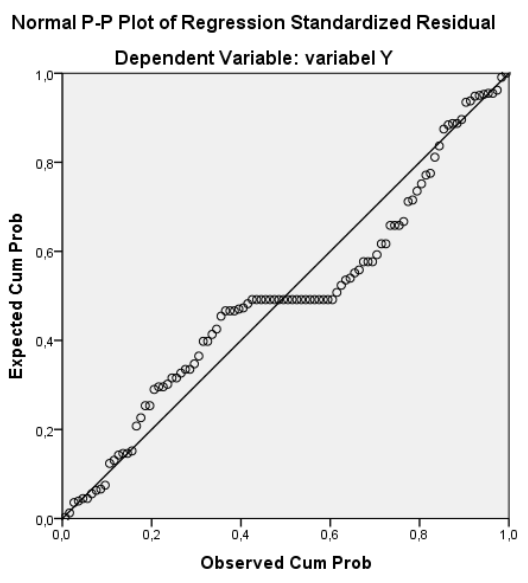

Figure 1. Result of normality test.

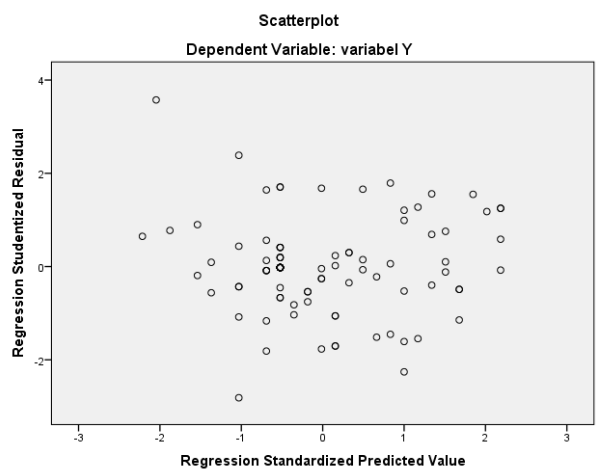

Figure 2. Result of Heteroskedasticity Test.

scale consists of sixteen items. All items on the scale are favorable items and scoring uses a Likert scale of $5=$ Strongly Agree to $1=$ Strongly Disagree. Examples of items from a scale such as: "The material, curriculum, and instructors of the training that I attended are appropriate to the needs". An item is considered a valid standard and is appropriate to use if it has a total item correlation coefficient above 0.2 [8].

The training scale has a reliability value of $\alpha=0.894$. Based on standards set that a good reliability value to be used as an instrument for research data collection is > 0.6 [9]. In addition, it was found that all items used had an adequate total item correlation $(r>0.2)$, thus they were considered able to measure the contract consistently. It can be concluded that the training scale has a good reliability value therefore it can be used as an instrument for research data collection.

The performance scale used consists of 18 items covering three dimensions, namely task behaviours, interpersonal facilitation behaviours, and job dedication. The scale used is Likert (1-5, 1 = Strongly Disagree, 5 = Strongly Agree). This scale has a favorite item. For example like "I carry out the responsibilities written in my job description".

Based on the calculation of item analysis on the performance scale shown on Table 4-7, there is 1 item that cannot function properly $(\mathrm{r}<0.2)$, thus only 17 items are used in the data collection process. From the results of the analysis after removing 1 item, the performance scale has a reliability value of $\alpha=0.895$, with an adequate total item correlation $(r>0.2)$.

For this study, researchers used a simple linear regression analysis model. Analysis using this model is based on a causal functional relationship on one independent variable 


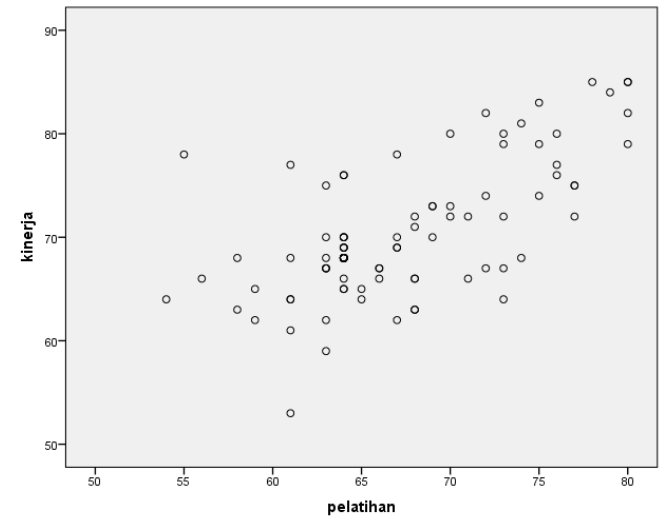

Figure 3. Result of linearity test.

with a dependent variable. Regression analysis aims to predict how high the value of the dependent variable if the value of the independent variable is manipulated or changed. But before conducting a regression analysis, researchers need the analysis of the prerequisite test/assumption test that is normality test, heteroscedasticity test, and linearity test.

\section{RESULT}

In this section, the authors describe the results of the research conducted, which consists of a description of training and performance on participants and also the results of a simple regression test to determine the role of training on the performance of seafarers. First explained the level of training of the participants that have been carried out by them.

From Table 8 it can be seen that the level of participant training is medium/moderate. Furthermore, an overview of the level of performance is carried out and the results are as shown in Table 9.

From Table 9 it appears that the dominant seafarers have quite good performance. Assumption Test Results

In the PP plot there is a plot line and a histogram line in Figure 1. The histogram line shows the distribution pattern that deviates to the right, which means it is a normal distribution. Furthermore, the dots follow and approach a diagonal line, therefore it can be concluded that the distribution is normal.

Looking at the plots graph between the predictive value of the variable bound to the residual in Figure 2, then the point of spread is seen, it is said that this does not occur heteroscedasticity, therefore it is concluded that the regression model meets the heteroscedasticity test.

Based on the scatter plot graph in Figure 3, the plot points can be seen forming a straight line from bottom left to top right. This shows the existence of a linear and positive relationship. This means that the higher the training, the performance will increase. Simple Regression Test shown on Table 10 are the results of the statistical analysis of the simple regression test conducted.

Table 10 shows that training can explain $44.5 \%$ of performance $(\mathrm{R}$-square $=0.445, \mathrm{p}<0.00)$. In this case, a score of 23,100 indicates a constituency value, indicating that if there is no increase in training the performance will reach 23,100 . while the price of $0.703 \mathrm{X}$ is a regression coefficient which shows that every additional 1 value/number for training there will be an increase in performance of 0.703 . Based on the results of the simple regression test in table 10 it was found that training contributed positively by $44.5 \%$ to seafarers' performance significantly, therefore the research hypothesis was accepted.

\section{DISCUSSION}

In accordance with the research hypothesis, it was found that safety training had a positive role in performance. Seafarers who have high training will also show high scores on performance. This can be explained that the provision of appropriate and quality training for seafarers will have a positive impact on working for these seafarers. Welldesigned training can produce learning experiences with positive applied. With the training, the employees can correct their shortcomings in doing work because while attending the training process seafarers are taught to be able to carry out work properly by training instructors who master the training material thus after attending seafaring training programs can minimize errors in work and can give an impact in the form of good performance improvement.

Associated with the results of the regression calculation showed that there was a significant contribution of training to the performance of $44.7 \%$. Based on table 8 , the most training level categories are from the medium category. The dominant seafarers agreed that after attending the training there was a follow-up to the utilization of training results (70\%). They agreed that the material, curriculum, and instructors were in accordance with the needs (69\%). As many as $63 \%$ thought that the training was planned carefully. The system provided is in accordance with the competency requirements of his position (61\%).

The training that was followed could contribute to carrying out the work (58\%), adding expertise $(56 \%)$, their knowledge and insight were increasing (55\%) and training could change attitudes and behaviours for the better (52\%). They acknowledged that the knowledge and skills gained through training could be applied to their work environment (69\%). In completing their work they are more confident than before training (64\%). The training that has been followed adds to the sense of responsibility towards his work $(61 \%)$. After completing the training they felt the work could be done better $(61 \%)$. In addition, they teach their colleagues about new knowledge or methods gained from training $(62 \%)$. They argue that evaluating the implementation of training needs to be done for future reference $(66 \%)$.

This is consistent that training is a systematic process of changing employee behaviours in a direction to improve organizational goals [10]. Training is a planned concept which is the design of interventions in order to produce the understanding needed to improve the performance of its employees [11].

Based on table 9, the highest category of performance is the medium category. This means that the majority of seafarers have sufficient performance. They can simply carry out their duties both task performance (task performance behavior) and contextual performance (interpersonal facilitation behaviours and job dedication behaviours). If it is associated with 3 performance indicators, the overall results will be obtained as follows.

In the aspect of task performance behaviors, it is seen that as many as $71 \%$ of seafarers carry out the responsibilities written in the job description. They carry out their tasks as expected (67\%), fulfill the formal performance 
requirements/requirements of their work (66\%), do things that will directly affect their performance appraisal (62\%). As many as $59 \%$ performed the assigned tasks quite well, they did not neglect the work they were supposed to do $(37 \%)$.

Regarding interpersonal facilitation behaviors, it is seen that as many as $68 \%$ of seafarers help their team members/co-workers without being asked. They also discussed with their team members/co-workers before taking actions that might affect them (64\%). $62 \%$ treat their team members/co-workers fairly. If he have a personal problem, they give advice to colleagues (60\%). They also praise each other team members/co-workers if they successfully complete the task (59\%).

Regarding job dedication behaviors, $74 \%$ of seafarers like challenging work assignments. They continue to overcome obstacles in completing tasks (72\%) and overcome difficult work tasks with enthusiasm (70\%), paying close attention and important details (70\%). As many as $68 \%$ of seafarers took the initiative to learn new skills, took the initiative to overcome work-related problems $(67 \%)$. In doing their work they train themselves to be disciplined (56\%).

Previous studies have shown that there is indeed a close relationship between training and performance. In 2011, training and feedback can improve the performance of all types of organizations, and by disseminating these implications and other more advanced training factors, the quality of team processes can be improved which will result in better forms for employee performance [12]. In 2013, training had a positive impact on employee performance [13].

Other research shows that the contribution of training variables to the employee performance variable at $\mathrm{CV}$ Cibalung Happy Land Bogor is $13.6 \%$ [14]. In line with before, research results partially showed that the variables of job training and work motivation had a positive and significant effect on the performance of the employees at PT. PCI Electronics International. And the results of the study simultaneously show that all independent variables have a positive and significant effect on employee performance [15]. Research results also showed the effect of job training on the performance of employees at PT Padma Ardya Aktuaria Jakarta by $25.7 \%$ while the rest were influenced by other variables [15].

Likewise with the research of Riani et al., The results showed that the training had a significant and positive effect on the performance of the employees of PT. TD Automotive Compressor Indonesia [16]. In the same year, the results of the analysis of Julianry's research data resulted in findings at the Ministry of Communication and Information the training variable significantly had a positive effect on employee performance but had a negative effect on organizational performance [19]. So the results of this study can support previous research and even strengthen existing research.

\section{CONCLUSION}

The results showed that safety training had a significantly positive role of $44.5 \%$ in seafarers' performance. This indicates how big the role of safety training is because it has an impact on the better performance of seafarers. Quality of human resources, rapid and continuous change, problems of technology transfer, global competition, are some of the things that cause the need for training. The implementation of good training certainly takes into account the needs of the company today in order to improve and enhance HR performance. Thus, the safety training program becomes a matter of concern to improve the performance of seafarers.

Based on the results of research that researchers have done, researchers have possible suggestions for consideration. For further research, it is better to add other independent variables in order to be able to explain more broadly about seafarers 'performance, because there are still other variables outside this study that might affect seafarers' performance. This is to be able to produce a more complete picture of the research problem being studied thus later it will be more complete the phenomenon of seafarers' performance.

This research also has implications that seafarers can improve their performance through training. For seafarers, it is advisable to find and follow a training program, which is held in the relevant agencies or institutions. For shipping companies, they can make a good training program thus seafarers are knowledgeable, supportive and experienced. With training, seafarers are expected to be more skilled, thus seafarers will be able to complete their tasks, face problems in the environment effectively and optimally.

\section{REFERENCES}

[1] R. James and J. Stephan, "Interpersonal Facilitation And Job Dedication As Separate Facets Of Contextual Performance," J. Appl. Psychol., vol. 81, no. 5, pp. 525-531, 1996.

[2] J. Stephan, Job Performance. Handbook of Psychology Vol 12 Industrial and Organizational Psychology. John Wiley \& Sons Inc, 2005.

[3] B. Nancy and H. Keith, "Valuing Task And Contextual Performance: Experience, Job Roles, And Ratings Of The Importance Of Job Behaviourss," Appl. H.R.M. Res., vol. 8, no. 1, pp. 17-32, 2003.

[4] K. Linda, M. Claire, H. Vincent, B. Wilmar, C. Henrica, and J. Allard, "Conceptual Frameworks Of Individual Work Performance A Systematic Review,” Am. Coll. Occup. Environ. Med., vol. 53, no. 8, 2011.

[5] D. Gary, Manajemen SDM. Jakarta: Indeks, 2009.

[6] N. Rini, "Identifikasi Budaya Perusahaan Pelayaran," J. Poseidon Fak. Psikol. Univ. Hang Tuah, vol. 9, no. 2, pp. 17-27, 2015.

[7] Sugiyono, Metode penelitian kuantitatif, kualitatif dan $r \& d$. Bandung: Alfabeta, 2011.

[8] M. Nisfiannoor, Pendekatan Statistika Modern Untuk Ilmu Sosial. Jakarta, Indonesia: Salemba Humanika, 2009.

[9] A. Saifudin, Penyusunan Skala Psikologi. Yogyakarta: Pustaka Pelajar, 2012.

[10] R. Mathis and J. Jackson, Manajemen Sumber Daya Manusia. Jakarta: Salemba Empat, 2001.

[11] McKenna and N. Beech, Manajemen Sumber Daya Manusia. Yogyakarta: Andi Publisher, 2000.

[12] F. Mubashar and A. Muhamamd, "Impact of Training and Feedback on Employee Performance," Far East J. Psychol. Bus., vol. 5, no. 1, 2011.

[13] E. Amir and I. Amen, "The Effect of Training on Employee Performance," Eur. J. Bus. Manag., vol. 5, no. 4, p. 137, 2013.

[14] Sugiarti, H. Tuti, and A. Hafniza, "Pengaruh Pelatihan Kerja Terhadap Kinerja Karyawan Pada PT Padma Ardya Aktuaria Jakarta," Epigram, vol. 13, no. 1, 2016.

[15] R. Nur and M. Priskila, "Pengaruh Pelatihan Kerja dan Motivasi Kerja terhadap Kinerja Karyawan Bagian PT. PCI Elektronik International (Studi pada Karyawan PT PCI Elektronik International)," J. Akuntansi, Ekon. dan Manaj. Bisnis, vol. 4, no. 1, pp. 41-46, 2016.

[16] E. Maulia, M. Syamsul, and A. Joko, "Pengaruh Program Pelatihan Dan Motivasi Kerja Terhadap Kinerja Karyawan PT. TD Automotive Compressor Indonesia," J. Apl. Bisnis Dan Manaj., vol. 3, no. 2, 2017. 